\title{
Habitat displacement effect between two competing owl species in fragmented forests
}

\author{
Lukasz Kajtoch $^{1}$ (D) Michał Żmihorski ${ }^{2} \cdot$ Paweł Wieczorek $^{3}$
}

Received: 2 August 2014 / Accepted: 29 May 2015/Published online: 18 June 2015

(C) The Author(s) 2015. This article is published with open access at Springerlink.com

\begin{abstract}
Many owl species use the same nesting and food resources, which causes strong interspecific competition and spatio-temporal niche separation. We made use of a recent colonisation of Ural Owls (Strix uralensis) in southern Poland to compare habitat preferences of Tawny Owls (Strix aluco) allopatry and sympatry with Ural Owls. We investigated spatial niche segregation of Ural Owl and the Tawny Owl in sympatry and compared habitat preferences of Tawny Owls breeding in allopatry and sympatry. Tawny Owls breeding in sympatry with Ural Owls occupied forests with higher canopy compactness, sites located closer to forest border and to built-up areas, as well as stands with a higher share of fir and spruce and a lower share of beech as compared to sites occupied by Ural Owls. Allopatric Tawny Owls occupied sites with lower canopy compactness and bred at sites located further from forest borders and in stands with lower share of fir and spruce and a higher share of deciduous as compared to sympatric Tawny Owls. As Ural owls are dominant in relation to
\end{abstract}

The authors Łukasz Kajtoch and Michał Żmihorski have contributed equally to this work.

Electronic supplementary material The online version of this article (doi:10.1007/s10144-015-0497-y) contains supplementary material, which is available to authorized users.

Łukasz Kajtoch

lukasz.kajtoch@gmail.com

1 Institute of Systematics and Evolution of Animals, Polish Academy of Sciences, Sławkowska 17, 31-016 Krakow, Poland

2 Department of Ecology, Swedish University of Agricultural Sciences, Box 7044, SE 75007 Uppsala, Sweden

3 Regional Directorate for Environmental Protection in Krakow, Plac Na Stawach 3, 30-107 Krakow, Poland
Tawny Owls, this indicates that the presence of Ural Owls prevents Tawny Owls from occupying deciduous-dominated and old stands located in forest interior areas, far from buildings and forest edges. The results support habitat displacement between the two species when breeding in sympatry. We also show that protection of large forest patches is crucial for the Ural Owl, a species still rare in central Europe, while small patches are occupied by the abundant Tawny Owl.

Keywords Habitat fragmentation - Intraguild predation . Spatial segregation $\cdot$ Strix aluco $\cdot$ Strix uralensis $\cdot$ Sympatry

\section{Introduction}

In ecologically similar and evolutionarily related species, distribution ranges may be geographically separated due to competitive interactions (Schoener 1982; Cody 1985). Such species show intense interspecific territorial activity when living in sympatry; range extensions leading to their sympatry are often accompanied by niche compression (MacArthur 1972; Swihart et al. 2003). At this stage, the species are expected to first segregate in terms of their habitat niches (MacArthur and Wilson 1967) through niche shifts (Pianka 1981) or through niche shrinking by one or both competitors (Newton 1998). Finally, this results in habitat displacement (Caccamise 1974), segregation between two species (Cody 1985), or competitive suppression-exclusion by interference competition (MacLean and Seastedt 1979; Sergio and Hiraldo 2008). In heterogeneous habitats (e.g., fragmented forests), the most suitable localities are generally first occupied by the dominant species (Fretwell 1972). These effects could be particularly visible in guilds of predators that often constitute top 
predators and subordinate mesopredators (e.g., Kostrzewa 1991; Tannerfeldt et al. 2002; Zuberogoitia et al. 2005; Berger and Gese 2007; Chakarov and Krüger 2010; Sergio et al. 2007).

Among birds, the Strix owl species are an excellent model species for studying interspecific competition because they are closely related both phylogenetically and ecologically and are distributed in different areas allo-, para- and sympatrically. In Europe, three Strix owls can be used in competition research, but only two of them inhabit central Europe in larger numbers: the Ural Owl Strix uralensis Pallas 1771 and the Tawny Owl Strix aluco Linnaeus 1758 . These two species only breed parapatrically or sympatrically in two areas: (1) from southern Scandinavia to central Russia and Belarus (subspecies $S$. u. liturata) and (2) in the Carpathian Mountains, the Balkan Mountains and the Dynaric Alps (subspecies S. u. macroura) (Hagemeijer and Blair 1997). Strix uralensis macroura has expanded its range since the end of the 20th century: it spread throughout the Carpathians and the Polish-Ukrainian Uplands (Tomiałojć and Stawarczyk 2003; Bashta 2009). The niche relationships of the two sympatric Strix owl species have been studied with respect to their food, nest, and habitat preferences and their diurnal and vocal activity (von Haartman 1968; Schoener 1974; Korpimaki 1986). Both species broadly overlap with respect to their food preferences (Lundberg 1980; Korpimaki 1986; Korpimaki and Sulkava 1987; Jędrzejewski et al. 1994; Tschechkin 1997; Romanowski and Żmihorski 2009; Kociuba 2012) and occupy similar nest sites: holes and stumps in large trees and nests of diurnal raptors (Korpimaki 1986; Lahti 1972; Vrezec and Kohek 2002; König and Weick 2008). The Tawny Owl is nocturnal with respect to its hunting and vocal activity, while the Ural Owl shows a bimodal dusk/dawn activity pattern. The Ural Owl is aggressive towards the Tawny Owl (Vrh and Vrezec 2006), whereas the latter species mostly avoids interactions. The habitat preferences of these two species overlap to a great extent, as both inhabit forests. The Ural Owl mostly occupies extensive forests of different kinds, often in the vicinity of peat bogs and clearings (Lahti 1972; Lundberg 1980; Mihelič et al. 2000; Bylicka et al. 2010). The Tawny Owl is a generalist species that can inhabit various types of woods including large forests (Mikkola 1983; Goszczyński et al. 1993; Turzański 2009a) and small patches in agricultural matrix (Petty 1989; Redpath 1995; Ranazzi et al. 2000).

Studies from Scandinavia indicate keen interspecific competition between both of these Strix owls (Lundberg 1980; Korpimaki 1986). Studies from central Europe either rejected competition between the two species in places where the Ural Owl has been reintroduced (Stürzer 1998) or confirmed habitat or altitudinal segregation in natural populations
(Vrezec 2003; Vrezec and Tome 2004a, b; Bolboacă et al. 2013). However, all previous investigations have been conducted in large, extensive boreal forests in Scandinavia and Belarus (Lundberg 1980; Korpimaki 1986; Tschechkin 1997) or montane forests in the Dinaric Alps, Moldavian Plateau, and Bohemian Forest (Stürzer 1998; Vrezec 2003; Vrezec and Tome 2004a, b; Bolboacă et al. 2013). However, nothing is known about the competition and spatial segregation of these two species in fragmented forests. This subject has never been studied, as there are almost no Ural Owl populations in such a landscape. An exception is the Carpathian Foothills, where both species have co-occurred sympatrically since the Ural Owl's expansion started four decades ago (Kajtoch 2006; Bylicka et al. 2010).

Manipulative experiments are probably not feasible for investigating top predators because it is extremely difficult to examine populations in large areas of a fixed state (e.g., habitat conditions, food resources) and to manipulate species demography to obtain selected parameters (e.g., distribution, densities, reproductive success, etc.). Instead, investigations on natural borders of species range can provide unique and important insights despite their obvious limitations. In this study we therefore used observational data concerning co-occurrence of two owl species when the range of one of them is restricted. The aim of this paper is to analyse spatial and habitat relations between the two Strix species with respect to their sympatric and allopatric distribution in a landscape with a limited area of favourable habitat (forest patch). The before-after control-impact experiment would have been the best solution in this case, yet was unrealistic, as the expansion of the Ural Owl in the Foothills started approximately 40 years ago (Kajtoch 2006; Bylicka et al. 2010). Despite this, a comparison of the 'control' and 'impact' landscapes allows us to conduct a reliable analysis of niche segregation between the two species. Data about differences in the distribution of the Tawny Owl are used for evaluating the influence of the presence of a top predator (Ural Owl) on the occurrence of the mesopredator (Tawny Owl) in fragmented forests. Selected landscapes provide an interesting 'natural experiment' for evaluating whether the observed distribution of the two owls supports the displacement hypothesis. Finally, this study was used for discussion of conservation priorities for forest-dwelling owls in fragmented landscapes.

\section{Materials and methods}

\section{Study area}

The study was conducted in two adjacent landscapes in southern Poland. One landscape was located in the 
Carpathian Foothills $\left(250 \mathrm{~km}^{2}\right.$, landscape centre: $49^{\circ} 52^{\prime} 42^{\prime \prime} \mathrm{N} ; 20^{\circ} 14^{\prime} 9^{\prime \prime} \mathrm{E}$ ) and the other in the Kraków Uplands $\left(240 \mathrm{~km}^{2}, 50^{\circ} 3^{\prime} 25^{\prime \prime} \mathrm{N} ; 19^{\circ} 43^{\prime} 24^{\prime \prime} \mathrm{E}\right)$. Both landscapes consist of a forest and open land mosaic, in which forest patches amount to 12 and $13 \%$ of the Foothills and Uplands, respectively. Both landscapes have rugged topography including many hills and valleys $(230-430 \mathrm{~m}$ a.s.l. in the Foothills; 200-390 m a.s.l. in the Uplands). These landscapes were chosen for the study as they are either inhabited by both owl species (Foothills; Kajtoch 2006) or by only Tawny Owl (Uplands; Turzański 2009a), what provides an opportunity to use these two areas as "natural experiment" for a comparison of the distribution of the Tawny Owl with respect to the presence or absence of the Ural Owl.

As environmental conditions in the aforementioned landscapes are very similar, the following description concerns both of them. Most forest patches consist of a network of deciduous, coniferous, and mixed patches. Almost all forest patches in both studied landscapes are managed. Forest patches are situated mostly on slopes of hills, in gorges, and along larger streams and rivers. These forests are composed mainly of oaks Quercus spp., pines Pinus spp, hornbeams Carpinus betulus, birches Betula sp., firs Abies alba, beeches Fagus sylvatica, and spruces Picea abies. Semi-natural habitats like oak-forests (Luzulo luzuloidis-Quercetum), hornbeam-forests (Tilio-Carpinetum), beech-forests (Dentario glandulosae-Fagetum, Luzulo luzuloidis-Fagetum), fir-forests (Abietum polonicum), pine-forests (Leucobryo-Pinetum), and alder-elm (Alno-Ulmion) forests are limited to steeper slopes and swampy areas. In both landscapes, the predominating tree species are pine and beech, with lower proportion of fir and spruce (Table S1 in Electronic Supplementary Material). Most forest patches are fragmented and fully or partially isolated from each other (some are connected via wooded corridors along streams and field edges). There are 27 and 26 independent patches in the Foothills and Uplands, respectively. In both landscapes, the average age of the predominant trees in forest patches is $85-90$ years. The average volume of wood is similar in both landscapes $\left(312 \mathrm{~m}^{3} / \mathrm{ha}\right.$ in the Foothills and $309 \mathrm{~m}^{3} / \mathrm{ha}$ in the Uplands, http://www.krakow.lasy.gov.pl/). Buildings in villages are situated mostly along roads. Open areas are composed of arable fields, grasslands, and wastelands. These two landscapes were chosen as they are very similar with respect to topography and forest patch structure and they are close situated to each other (approximately $20 \mathrm{~km}$ ) but isolated from the area of the city of Kraków (see Fig. 1).

\section{Owl census}

The territories of the Ural Owl and the Tawny Owl were located by broadcasting their hooting and listening to the adult birds during the peak of their breeding activity from February to April, according to the methodology of owl detection (e.g., Redpath 1995; Mori et al. 2014). The voices of both owl species were used in both studied areas during the same night, but not simultaneously to detect all Tawny Owl territories, as the Ural Owl is aggressive towards the Tawny Owl (Vrh and Vrezec 2006). Moreover, the calls of juvenile owls, which have intensive and loud vocalization (Mikkola 1983), were inventoried to from May to June to verify the locations of the centres of owl territories. Two to five surveys per forest patch were conducted during the study period (in 2007 in the Uplands and in 2009 in the Foothills). Inventory of owls in different years should not influence results, as the distribution of owls in some parts of both areas has been inventoried several times since 1995 (Foothills) and 2000 (Uplands), and most territories were found to be constant through time (Kajtoch 2006; Turzański 2009a; Bylicka et al. 2010; P. Wieczorek, unpublished data). However, the Ural Owl has never been observed in the Uplands during breeding period. Broadcast stations (where playback of owls voices was executed) distribution depended on the forest patch area: in small patches $\left(<1 \mathrm{~km}^{2}\right)$ only one or two such points were chosen, while in larger ones stations were located in a grid with a distance of approximately $500 \mathrm{~m}$ apart. In total, broadcasting was conducted in 100 stations (approximately 50 in each area). Bird records were GPS-marked and plotted on topographic maps $(1: 25,000)$. Observations of territorial owls, pairs, nests, or juveniles during the breeding periods were used to select centres of territories. Single birds observed without territorial activity or confirmation of breeding (despite several surveys) were not considered in further analyses. Forest patch was assigned as 'unoccupied' if no owls were detected during the inventory. We put emphasis on recording simultaneously hooting males (Galeotti and Pavan 1993; Galeotti 1998) and on localization of calling juveniles (which confirms breeding status and allows for determination of the centre of territory). For visualization (Fig. 1) we used average areas of territories known for both species, however real home ranges of observed owls were unknown as they may vary substantially depending on several factors like stand type and food availability (Sunde 2011). The area of Ural Owl territory is known to cover on average 400 ha of forests and adjacent areas, and the Tawny Owl usually occupies 35-50 ha (Mikkola 1983; Bylicka et al. 2010; Cios and Grzywaczewski 2013). 
Fig. 1 Distribution of territories of the Tawny Owl and the Ural Owl in fragmented forests located on two landscapes (Uplands and Foothills) in Southern Poland. Location of the two landscapes are marked in the contour of Poland

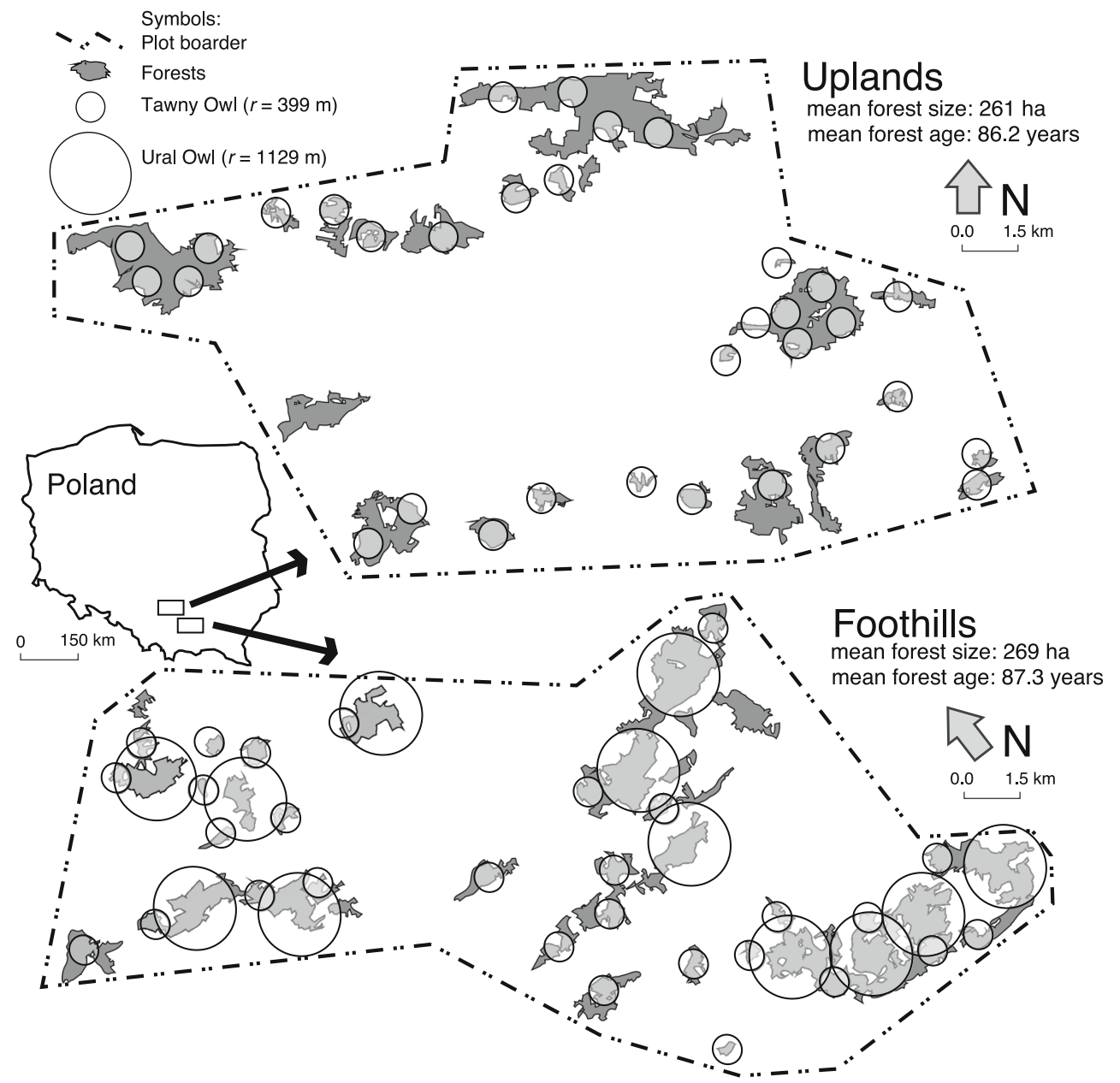

\section{Habitat characteristics}

The following habitat and spatial factors were chosen as potentially important for the presence of the owls: (1) Forest.SizE; (2) Forest.AGE; (3) Forest.BufFer; (4) Dist.ecoton; (5) Dist.buildings; (6) Canopy.Compactness; and domination of tree species: (7) PINE; (8) FIR \& SPRUCE; (9) BEECH; (10) OAK; (11) HORNBEAM \& BIRCH (Table 1). Factor 1 was attributed to the forest complex whereas rest of the factors was attributed to centre of owl territory (more specifically, to forest stand in which the centre was determined). Factors 1-2 and 5-6 were obtained from forestry maps (e.g., http://rdlpkrakow.gis-net.pl/). Factors 3-4 were calculated from geographic maps and aerial photographs using the GIS (http://maps.geoportal.gov.pl/webclient/ and Quantum GIS Development Team 2014).

\section{Statistical analysis}

Two statistical procedures were applied. First, we investigated whether the abundance of the Tawny Owl in the forest patches was affected by the presence of the Ural Owl in these patches. For this purpose, we used generalized linear mixed model (GLMM) with Poisson error distribution and log link. In this model, each forest patch was used as a separate data record, abundance of the Tawny Owl in a forest patch was used as a response variable, presence of the Ural Owl as fixed categorical factor (present vs. absent), and plot (Foothills vs. Uplands) as random categorical factor. Because the number of territories recorded is mutually dependent on the area inventoried (forest area highly significantly affected number of territories of the Tawny Owl, $P \ll 0.001$ ), the area of a forest complex (logtransformed) was included as an offset in the GLMM. The computations were conducted with the help of 'Ime4' package (Bates et al. 2014) in R program ( $R$ Development Core Team 2013).

Second, we compared the characteristics of the Ural and Tawny Owl centres of territories in the Foothills, where the two species co-occur, as well as Tawny Owl centres of territories between the Foothills (i.e., the landscape settled by the Ural Owl) and the Uplands (i.e., the landscape without the Ural Owl). For this purpose we used comparisons of density estimates of the two compared groups of 
Table 1 Mean values (with SE in brackets) of habitat characteristics measured for owl territories in two landscapes: Uplands (only Tawny Owl present) and Foothills (both species present). Habitat characteristics number 7-11 were measured in the same method and have the same units

\begin{tabular}{|c|c|c|c|c|c|c|}
\hline Number & Abbreviation & Description and units & Range & $\begin{array}{l}\text { Ural Owl } \\
\text { Foothills }\end{array}$ & $\begin{array}{l}\text { Tawny Owl } \\
\text { Foothills }\end{array}$ & $\begin{array}{l}\text { Tawny Owl } \\
\text { Uplands }\end{array}$ \\
\hline \multicolumn{7}{|c|}{ Attributes of forest complex } \\
\hline 1 & FoREST.SIZE & Total area of a forest, ha & $10-834$ & $426.6(267.2)$ & $253.4(275.5)$ & $288.1(285.6)$ \\
\hline \multicolumn{7}{|c|}{ Attributes of owl territory } \\
\hline 2 & FoREST.AGE & $\begin{array}{l}\text { Average age of the predominant type } \\
\text { of wood stands, years }\end{array}$ & $60-140$ & $103.3(21.5)$ & $85.7(24.6)$ & $87.9(21.9)$ \\
\hline 3 & FOREST.BUFFER & $\begin{array}{l}\text { Forest coverage of } 500 \mathrm{~m} \text { buffer } \\
\text { around the centre of an owl territory, } \\
\%\end{array}$ & $3.9-78.5$ & $64.8(10.6)$ & $45.3(16.0)$ & $51.5(24.8)$ \\
\hline 4 & Dist.eCoton & $\begin{array}{l}\text { Straight-line distance from the centre } \\
\text { of an owl territory to the nearest } \\
\text { forest edge, } \mathrm{km}\end{array}$ & $50-700$ & $462.5(143.2)$ & $225.0(106.7)$ & $298.5(178.3)$ \\
\hline 5 & Dist.BUILDINGS & $\begin{array}{l}\text { Straight-line distance from the centre } \\
\text { of an owl territory to the nearest } \\
\text { buildings inhabited by humans, km }\end{array}$ & $50-850$ & $579.2(157.3)$ & $337.5(171.4)$ & $431.8(192.0)$ \\
\hline 6 & CANOPY.COMPACTNESS & $\begin{array}{l}\text { Compactness of trees in dominating } \\
\text { wood layer, \% }\end{array}$ & $30-100$ & $49.2(14.4)$ & $79.6(17.8)$ & $64.8(0.21)$ \\
\hline 7 & PINE & \multirow{5}{*}{$\begin{array}{l}\text { Domination of tree species in the } \\
\text { forest compartment in which centre } \\
\text { of owl territory was assigned (five } \\
\text { categories were selected } \\
\text { corresponding to dominant tree } \\
\text { species in both landscapes), } 0 \text { vs } 1\end{array}$} & \multirow[t]{5}{*}{0 vs. 1} & $0.42(0.51)$ & $0.21(0.42)$ & $0.27(0.45)$ \\
\hline 8 & FIR\&SPRUCE & & & $0.00(0.00)$ & $0.25(0.44)$ & $0.00(0.00)$ \\
\hline 9 & BEECH & & & $0.42(0.51)$ & $0.04(0.19)$ & $0.18(0.39)$ \\
\hline 10 & OAK & & & $0.17(0.39)$ & $0.29(0.46)$ & $0.48(0.51)$ \\
\hline 11 & HORNBEAM\&BIRCH & & & $0.00(0.00)$ & $0.21(0.42)$ & $0.06(0.24)$ \\
\hline
\end{tabular}

centres of territories, with the permutation test of equality with 1000 permutations. In this analysis, each territory was used as separate data record. As a result, we received two distributions of every characteristic presented in Table 1 for two comparing groups of owl territories (e.g., UO Foothills and TO Foothills) and the statistical significance of the difference between them. On the basis of this analysis, we were able to infer about differences between comparing groups of territories. Computations were conducted with the help of ' $s m$ ' library (Bowman and Azzalini 2014) in R program (R Development Core Team 2013).

With increasing forest patch size, the number of territories (of both species) will also increase, which could be, at least partially, related with random sample effect (Andren 1996). Simply putting forest patch size into the model as a covariate will not address the problem concerning the consequences of different management strategies (e.g., removing large patches, removing small patches, etc.) for the two owl species. In order to investigate the consequences of landscape management and amount of habitat in different configurations for species conservation in the studied landscapes, we conducted additional analyses. Namely, we ranked forest patches in each landscape (Foothills and Uplands) from the smallest to largest, and from the largest to smallest (see e.g., Lennon et al. 2004). Then we calculated the cumulative number of territories observed for a given number of forest patches considered in the order of both small-to-large as well as large-to-small (two separate accumulation curves were created). As a result, for the number of forest patches considered, the cumulative number of territories and the cumulative area of forest habitat were known. We plotted the cumulative number of territories against the cumulative forest area for data from both landscapes and both owl species. With the help of this approach, we were able to show the effect of habitat configuration on birds controlling for the amount of habitat.

\section{Results}

\section{Distribution and abundance of the owls}

We recorded a total of 61 territories of the Tawny Owl and 12 territories of the Ural Owl. In the Uplands, it was only the Tawny Owl that was found to breed, despite the fact that several control checks were conducted to detect the other species. The Ural Owl was observed only twice in two localities in the Uplands: a single bird in the winter of 2005 and a single male in the autumn of 2008. In the Uplands, 33 territories of the Tawny Owl were recorded; this species occurred in all forest patches except four. In contrast, in the Foothills with 28 territories of Tawny Owl, this species was absent in six patches (Fig. 1). The average 


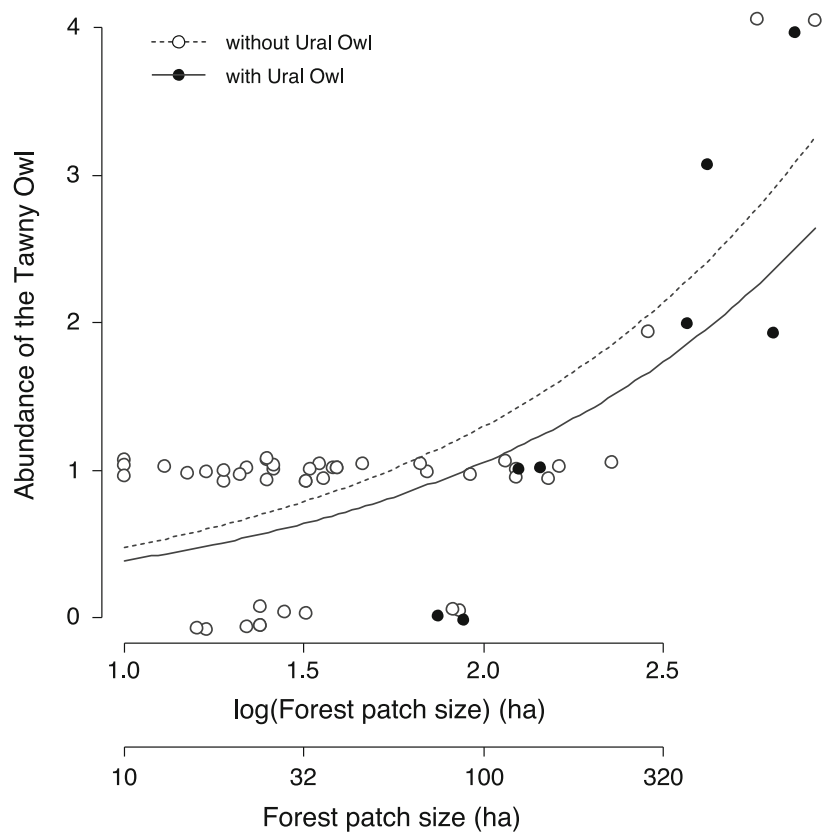

Fig. 2 Visualization of the fit of the generalized linear mixed model explaining abundance of the Tawny Owl as a function of presence of the Ural Owl and forest area controlled as an offset. The two curves visualize fit of GLMM explaining abundance of the Tawny Owl and refer to plots without Ural Owl (broken line, white circle) and with Ural Owl (solid line, black circles)

abundance of Ural Owl (in forest patches occupied by this species) was 1.5 territory/forest patch (range 0-2, $\mathrm{SD}=0.78$ ), whereas the abundance of Tawny Owls (also only in occupied forests) was 1.3 territory/forest patch (range $1-4, \mathrm{SD}=0.8$ ) for Foothills and 1.6 territory/forest patch (range $1-5, \mathrm{SD}=1.23$ ) for Uplands.

\section{The effect of presence of the Ural Owl on the abundance of the Tawny Owl}

The generalized linear mixed model revealed that the abundance of the Tawny Owl in a given forest patch was affected negatively by the presence of the Ural Owl in that patch (estimate $=-0.976, \quad \mathrm{SE}=0.34, \quad z=2.83$, $P=0.004$ ). Figure 2 visualizes the relationship together with the effect of forest size, which was included in the model as an offset.

\section{Comparison of territories of the Ural Owl and the Tawny Owl}

The mean values of the five habitat characteristics differed between the centres of territories of the two owl species cooccurring in the Foothills (Fig. 3). The Ural Owl territories were characterized (in comparison to sympatric Tawny
Owl territories) on average by 18 year older tree stands 1.7 times longer distances to buildings, 2.1 times longer distances to forest edge and a 1.4 times higher share of forested area within a buffer of $500 \mathrm{~m}$ of the territory centre. Canopy compactness was on average $40 \%$ lower in Ural Owl territories. The Ural Owl also demonstrates a high preference for beech and pine woods, whereas coexisting Tawny Owls inhabit mainly oak, pine and fir-spruce woods (Table 1; Fig. 3).

\section{Comparison of Tawny Owl territories in two landscapes}

The differences were recorded between the centres of territories of the Tawny Owl in the Uplands (allopatric to the Ural Owl) and the Foothills (sympatric with the Ural Owl). The latter were located on average in 1.3 times closer distances to forest edge, in 1.2 times higher coverage by forest within a buffer of $500 \mathrm{~m}$ of the territory centre and in forests with approximately $20 \%$ higher canopy compactness (Table 1). The Tawny Owl in the Uplands also shows greater occupancy of beech and oak stands and avoidance of fir and spruce and hornbeam and birch stands, which are not avoided by this species in the Foothills (Table 1; Fig. 3).

\section{Owls in a fragmented landscape}

The total afforested area is approximately 3400 ha in both landscapes ( 3407 ha in the Foothills and 3416 ha in the Uplands), so half of this afforested area amounts to approximately 1700 ha. The 1700 ha of the smallest forests (i.e., half of the habitat amount, composed of the smallest patches) in the Uplands hosts 20 territories of the Tawny Owl (i.e., $61 \%$ of its overall population in the Uplands), while in the Foothills the same area hosts 19 territories of the Tawny Owl ( $68 \%$ of the population). Forest patches of an area equal to $340 \mathrm{ha}$, that is, only $10 \%$ of the forest habitat, host 11 territories of the Tawny Owl in the Uplands and 10 territories in the Foothills, which constitute 33 and $36 \%$ of the overall population, respectively. The distribution pattern of the Ural Owl is different. The species is concentrated in the largest patches and is completely absent from the smallest forest patches amounting to 340 ha (i.e., $10 \%$ of the forest habitat). Five territories (i.e., $42 \%$ of overall population) are found in large forest patches comprising $50 \%$ of the forest habitat (i.e., 1700 ha, Fig. 4). This shows that distribution of territories of Tawny Owl and Ural Owl does not strictly follow the amount of forest habitat and that these two species show different patterns with respect to large and small patches. 


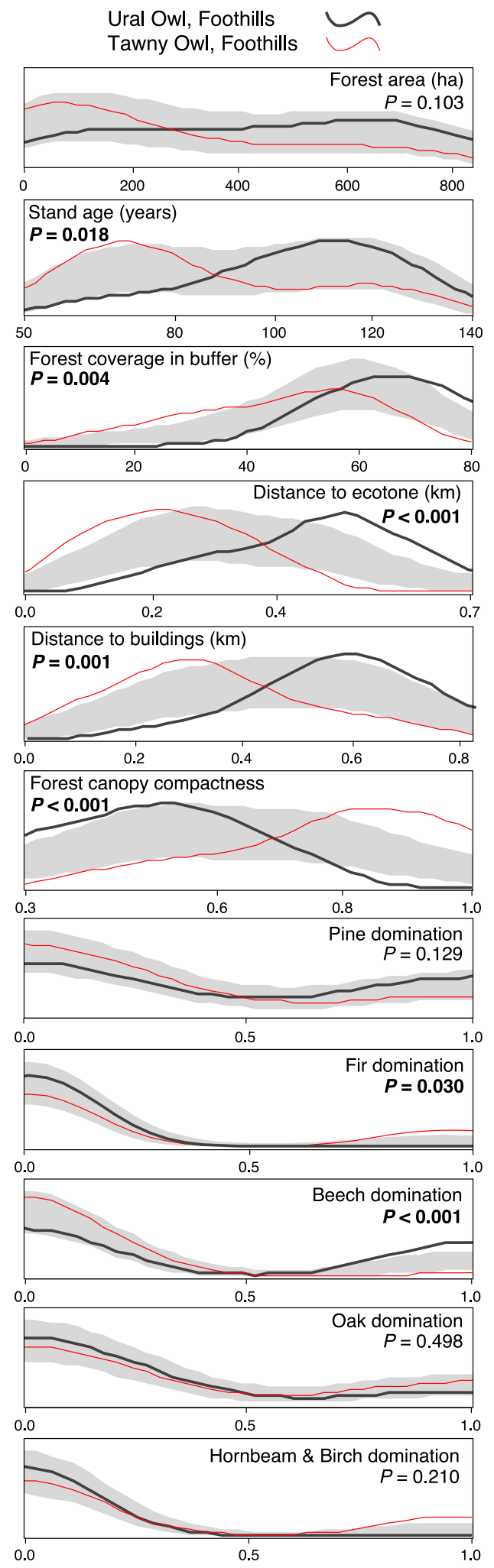

Fig. 3 Kernel density estimates visualizing distributions of the 11 characteristics of centres of owl territories. Left column of panels shows comparison of territories of Tawny and Ural Owls in Foothills; right column of panels shows comparison of territories of Tawny Owls from Foothills and Uplands. Lines indicate distribution of

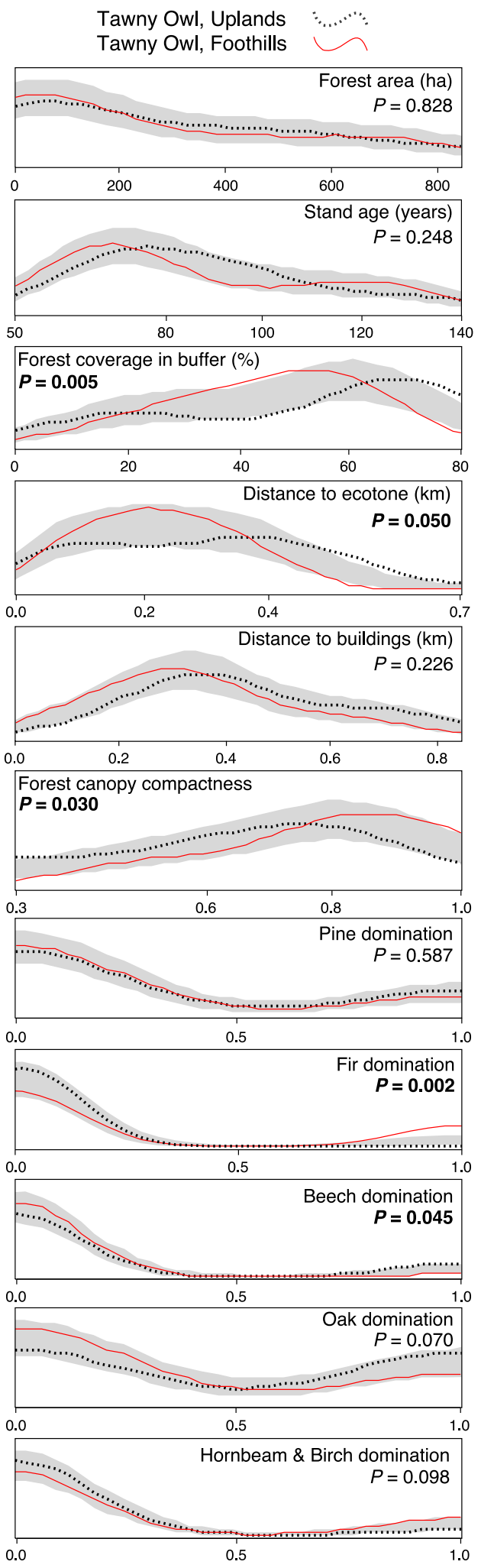

characteristics of a given species, grey areas indicate confidence bands for the two comparing species pooled. Results of permutation test is given for each comparison and significant differences are marked in bold. Order of the panels follows order of description of the 11 characteristics in Table 1 


\section{Discussion}

\section{Territorial displacement}

The Tawny Owl's distribution and habitat selection in fragmented forests is determined to some extent by the avoidance of the Ural Owl. Comparison of density estimates with the permutation test (see Fig. 3) suggests that Ural Owls force Tawny Owls to occupy younger and denser stands closer to edges and human settlements. Importantly, as revealed by the permutation tests, the Ural Owl prevents the Tawny Owl from breeding in centres of larger forest patches, which are usually dominated by older beech or pine stands (preferred by the Ural Owl in the Carpathian Foothills, Kajtoch 2006; Bylicka et al. 2010; Kociuba 2012) (Figs. 1, 3). The Tawny Owl is a generalist species that can inhabit various woods; however, it is adapted rather to old deciduous stands (Mikkola 1983; Goszczyński et al. 1993). This high plasticity in habitat selection possibly allows Tawny Owls to co-exist with top predators, not only the Ural Owl but also Eagle Owl Bubo bubo (Sergio et al. 2007) and Goshawk Accipiter gentilis (Turzański 2009a, b). However, as compared to these three species the Tawny Owl is always subordinate and avoids proximity to their territories. Consequently, we interpret the shift of Tawny Owl territories towards younger and denser woods as the effect of habitat displacement: spatial segregation forced by the presence of a stronger competitor and the top predator, the Ural Owl. However, it is important to highlight limitations of our study design resulting from unknown borders of territories and no data on the distribution of Tawny Owls in some Ural Owl-free plots in Foothills. These factors do not allow other reasons for this habitat displacement to be completely ruled out.

\section{The strength of spatial segregation}

Despite the fact that the spatial segregation has been observed between the studied owls, the overall impact of the Ural Owl on its subordinate cousin seems to be smaller than it might be expected. First of all, the abundance of Tawny Owl in the two landscapes is comparable. We recorded 28 territories of this species in the Foothills and 33 in the Uplands $(0.82$ and 0.97 territory per 100 ha of forest, respectively). The difference is not large and suggests that the effect of the presence of the Ural Owl is not strong, at least at the abundance level. Next, as small patches are not settled by the Ural Owl, one may expect that the Tawny Owl population should only be concentrated in such patches. In contrast to these expectations, the distribution of the Tawny Owl was similar in the Uplands and Foothills, but centres of largest forest patches in the Foothills were occupied exclusively by the Ural Owl (see Figs. 1, 4). However, we have no data on breeding success, offspring quality, or general fitness of particular individuals. These may be differentiated across a gradient of proximity to Ural Owl territories. Nevertheless, our data supports the displacement hypothesis and the spatial segregation effect on the distribution and abundance of the Tawny Owl; the observed effect was rather moderate, however. Usually, strong competition was observed among ecologically related predators (e.g., between Arctic Foxes Alopex lagopus and Red Foxes Vulpes vulpes, Tannerfeldt et al. 2002; Wolves Canis lupus and Coyotes Canis latrans, Berger and Gese 2007; Goshawks Accipiter gentilis and Common Buzzards Buteo buteo, Kostrzewa 1991). The example of intraguild predation with the Ural Owl and the Tawny Owl is similar to the situation of top predation of the Eagle Owl Bubo bubo and two mesopredators, the Goshawk and the Common Buzzard (Chakarov and Krüger
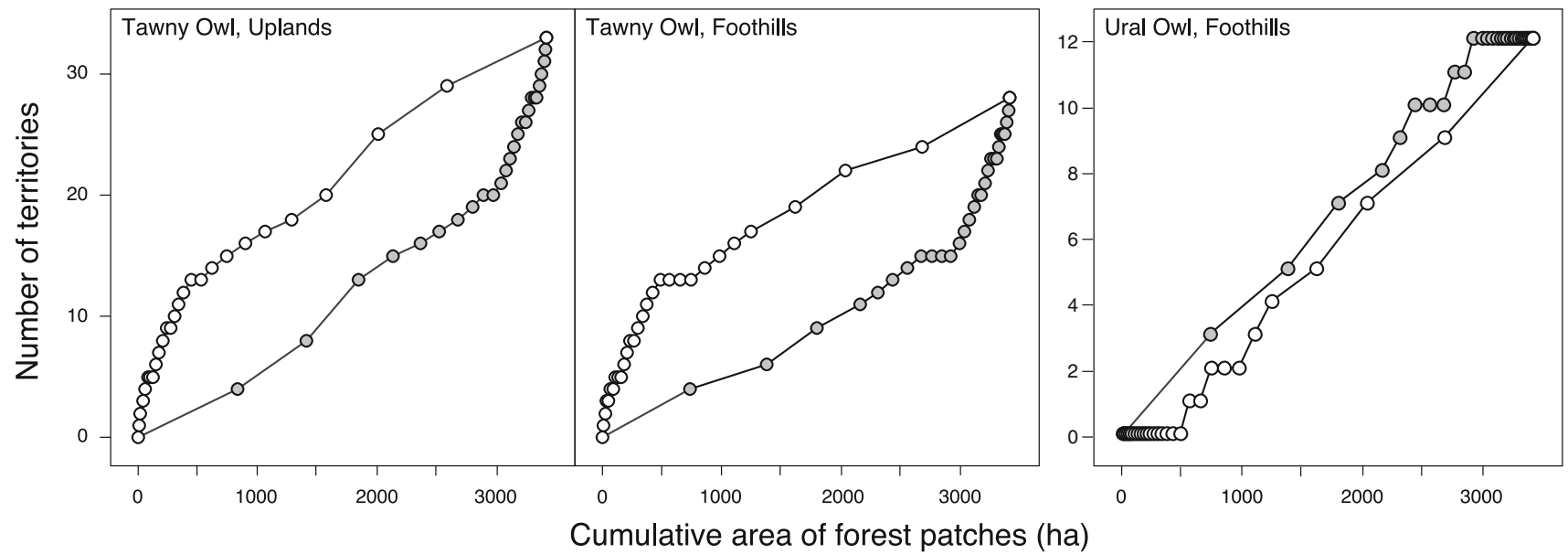

Fig. 4 Cumulative number of owls' territories ( ircles) in relation to cumulative forest patch size. Two ways of forest patch accumulation were applied: from the smallest to the largest (white circles) and from the largest to the smallest (grey circles) 
2010), which showed that subordinate species compete to breed in predator-free refugia. Also, Sergio et al. (2007) showed the Tawny Owls avoidance of proximity to Eagle Owl in the Alps. As deduced above, the moderate displacement effect could be caused by the high plasticity of the Tawny Owl with respect to habitat selection.

Other studies have shown either strong spatial segregation between the Ural Owl and the Tawny Owl (e.g., Lundberg 1980; Korpimaki 1986 in Scandinavia; Vrezec 2003; Vrezec and Tome 2004a, b in Dinaric Alps and Bolboacă et al. 2013 in Moldavian Plateau) or a lack of such competition (Stürzer 1998 in Bohemian Forest). Moderate habitat displacement between the Ural Owl and the Tawny Owl in our studies could also be compounded by the edge effect, as our Foothills landscape lies on the verge of the distribution range of the Ural Owl in the Carpathians. Local breeding pairs could breed less successfully than pairs in the centre of the range. The expansion of this species has not finished (Bylicka et al. 2010; Ł. Kajtoch, unpublished data) so it is interesting why this species has not settled in the Uplands yet. Despite the fact that this area lies only $20 \mathrm{~km}$ from their nearest territories in the Foothills, Ural Owls have never bred in the Uplands, including in 2013-2015 (Turzański 2009a; this study). We assume that the absence of the Ural Owl in the Uplands cannot be driven by a lack of nesting places or food availability, as such nesting places are available: goshawks and common buzzards are abundant breeders there (Turzanski 2009b). In the Foothills, Ural Owls feed on the same prey as Tawny Owls (Kociuba 2012); therefore, it can be assumed that there is sufficient food availability for the Ural Owl as well.

\section{The conservation implications}

The Ural Owl is concentrated in the centres of largest forest patches, while the Tawny Owl inhabits small patches or edges of larger patches. Protection of only larger forest patches would be beneficial therefore for the Ural Owl; however, elimination of smaller forest patches would considerably reduce the number of Tawny Owls, as these patches host nearly half of its population. Furthermore, despite the fact that the Ural Owl does not occur in small forest patches, it may utilize them for post-breeding dispersal (Bylicka et al. 2010). As we have previously shown, habitat connectivity in this area is crucial for another forest-dwelling species, the Hazel Grouse Tetrastes bonasia (Kajtoch et al. 2012). Conversely, exclusive protection of smaller forest patches would probably lead to the extinction of the Ural Owl, while benefitting the Tawny Owl, which could also affect other owls. The Ural Owl, when coexisting with the Tawny Owl, is thought to shelter the territories of the Boreal Owl Aegolius funereus, which is highly susceptible to Tawny Owl predation (Vrezec 2003; Vrezec and Tome 2004a). Indeed, in the studied areas, Boreal Owls were exclusively detected in the Foothills within Ural Owl territories (Kajtoch 2006) and were absent from the Uplands (Turzański 2009a; Ł. Kajtoch, unpublished data).

Nevertheless, if any decisions concerning forest management at landscape level must be made, large forest patches are absolutely crucial for the persistence of the Ural Owl, so they should definitely be preserved. The Ural Owl is still a rare species in central Europe and its conservation should take precedence over the protection of a much more abundant and widespread species, the Tawny Owl.

Acknowledgments We are grateful to Krzysztof Kus and Piotr Skucha for providing information about some owls territories. We thank to Tomas Pärt for helpful comments and discussion, and to anonymous reviewers for valuable suggestions to previous version of this article. This work was supported by grant 9007/IP1/2014/72 (Iuventus Plus) from the Polish Ministry of Science and Higher Education (to Łukasz Kajtoch).

Open Access This article is distributed under the terms of the Creative Commons Attribution 4.0 International License (http://creativecommons.org/licenses/by/4.0/), which permits unrestricted use, distribution, and reproduction in any medium, provided you give appropriate credit to the original author(s) and the source, provide a link to the Creative Commons license, and indicate if changes were made.

\section{References}

Andren H (1996) Population responses to habitat fragmentation: statistical power and the random sample hypothesis. Oikos $76: 235-242$

Bashta A-T (2009) Ural Owl Strix uralensis population dynamics and range expansion in western Ukraine. Ardea 4:483-487

Bates D, Maechler M, Bolker B, Walker S (2014). lme4: Linear mixed-effects models using Eigen and S4. R package version 1.0-6. http://CRAN.R-project.org/package $=1 \mathrm{me} 4$

Berger KM, Gese EM (2007) Does interference competition with wolves limit the distribution and abundance of coyotes? J Anim Ecol 76:1075-1085

Bolboacă LE, Baltag ES, Pocora V, Ion C (2013) Habitat selectivity of sympatric Tawny Owl (Strix aluco) and Ural Owl (Strix uralensis) in hill forests from north-eastern Romania. Analele Ştiinţifice ale Universităţii Alexandru Ioan Cuza din Iaşi, s. Biol Animală 59:69-76

Bowman AW, Azzalini A (2014) R package sm: nonparametric smoothing methods (version 2.2-5.4). URL http://www.stats.gla. ac.uk/ adrian/sm

Bylicka M, Kajtoch Ł, Figarski T (2010) Habitat and landscape characteristics affecting the occurrence of Ural Owl Strix uralensis in agroforestry mosaic. Acta Ornithol 45:33-42

Caccamise DF (1974) Competitive relationships of the common and lesser nighthawks. Condor 76:1-20

Chakarov N, Krüger O (2010) Mesopredator release by an emergent superpredator: a natural experiment of predation in a three level guild. PLoS One 5(12):e15229 
Cios S, Grzywaczewski G (2013) Znaczenie wybranych czynników kształtujących powierzchnie terytoriów puszczyka Strix aluco w lasach Lubelszczyzny. [Importance of selected factors influencing the size of tawny owl Strix aluco territories in the forests of Lublin region]. Sylwan 157:348-357 (in Polish with English abstract)

Cody ML (1985) An introduction to habitat selection in birds. In: Cody ML (ed) habitat selection in birds. Academic Press, London

Development Core Team R (2013) R: a language and environment for statistical computing. R Foundation for Statistical Computing, Vienna

Fretwell SD (1972) Populations in a seasonal environment. Princeton University Press, Princeton

Galeotti P (1998) Correlates of hoot rate and structure in male Tawny Owls Strix aluco: implications for male rivalry and female choice. J Avian Biol 29:25-32

Galeotti P, Pavan G (1993) Differential responses of territorial tawny owls Strix aluco to the hooting of neighbourds and strangers. Ibis 135:300-304

Goszczyński J, Jabłoński P, Lesiński G, Romanowski J (1993) Variation in diet of Tawny Owl Strix aluco L along an urbanization gradient. Acta Ornithol 27:113-123

Hagemeijer EJM, Blair MJ (1997) The EBCC atlas of European breeding birds: their distribution and abundance. $\mathrm{T} \& \mathrm{AD}$ Poycer, London

Jędrzejewski W, Jędrzejewska B, Zub K, Ruprecht AL, Bystrowski C (1994) Resource use by Tawny Owls Strix aluco in relation to rodent fluctuations in Białowieża National Park, Poland. J Avian Biol 25:308-318

Kajtoch Ł (2006) Sowy Strigidae Pogórza Wielicko-Wiśnickiego i Beskidu Wyspowego. [Owls Strigidae of Wieliczka-Wiśnicz Foothills and Beskid Wyspowy Mts]. Not Orn 47:252-259 (in Polish with English abstract)

Kajtoch Ł, Żmihorski M, Bonczar Z (2012) Hazel Grouse occurrence in fragmented forests: habitat quantity and configuration is more important than quality. Eur J Forest Res 131:1783-1795

Kociuba M (2012) Czynniki wpływające na skład diety puszczyka uralskiego Strix uralensis na Pogórzu Środkowobeskidzkim. [Factors affecting diet composition of the Ural Owl Strix uralensis at the Foothills of the Central Beskidy Mountains, SE Poland]. Not Orn 53:283-292 (in Polish with English abstract)

König C, Weick F (2008) Owls of the world, 2nd edn. Yale University Press, London

Korpimaki E (1986) Niche relationships and life-history tactics of three sympatric Strix owl species in Finland. Ornis Scand $17: 126-132$

Korpimaki E, Sulkava S (1987) Diet and breeding performance of Ural owls Strix uralensis under fluctuating food conditions. Ornis Fenn 64:57-66

Kostrzewa A (1991) Interspecific interference competition in three European raptor species. Ethol Ecol Evol 3:127-143

Lahti E (1972) Nest sites and nesting habitats of the Ural Owl Strix uralensis in Finland during the period 1870-1969. Ornis Fenn 49:91-97

Lennon J, Koleff P, Greenwood JJD, Gaston KJ (2004) Contribution of rarity and commonness to patterns of species richness. Ecol Lett 7:81-87

Lundberg A (1980) Why are the Ural Owl Strix uralensis and the Tawny Owl Strix aluco parapatric in Scandinavia. Ornis Scand 11:116-120

MacArthur RH (1972) Geographical ecology. Harper and Row, New York

MacArthur RH, Wilson EO (1967) The theory of island biogeography. Princeton University Press, Princeton
MacLean SF Jr, Seastedt TR (1979) Avian territoriality: sufficient resources or interference competition. Am Nat 114:308

Mihelič T, Vrezec A, Perušek M, Svetličič J (2000) Ural Owl Strix uralensis in Slovenia. Acrocephalus 21:9-22

Mikkola H (1983) Owls of Europe. Poyser, Calton

Mori E, Menchetti M, Ferretti F (2014) Seasonal and environmental influences on the calling behavior of Eurasian Scops Owls. Bird Study 61:277-281

Newton I (1998) Population limitation in birds. Academic Press, London

Petty SJ (1989) Productivity and density of Tawny Owls Strix aluco in relation to the structure of a British spruce forest. Ann Zool Fenn 26:227-233

Pianka ER (1981) Resource acquisition and allocation among animals. In: Townsend C, Calow P (eds) Physiological ecology: an evolutionary approach to resource use. Sinauer Associates, Sunderland, pp 300-304

Quantum GIS Development Team (2014) Quantum GIS geographic information system. open source geospatial foundation project. http://qgis.osgeo.org. Accessed 20 June 2014

Ranazzi L, Manganaro A, Ranazzi R, Salvati L (2000) Density, territory size, breeding success and diet of Tawny Owl Strix aluco population in a Mediterranean urban area (Rome, Italy). Alauda 68:133-143

Redpath SM (1995) Impact of habitat fragmentation on activity and hunting behavior in the tawny owl, Strix aluco. Behav Ecol 6:410-415

Romanowski J, Żmihorski M (2009) Seasonal and habitat variation in the diet of the tawny owl (Strix aluco) in Central Poland during unusually warm years. Biol Bratisl 64:365-369

Schoener TW (1974) Resource partitioning in ecological communities. Science 185:27-39

Schoener TW (1982) The controversy over interspecific competition. Am Sci 70:586-595

Sergio F, Hiraldo F (2008) Intraguild predation in raptor assemblages: a review. Ibis 150:132-145

Sergio F, Marchesi L, Pedrini P, Penteriani V (2007) Coexistence of a generalist owl with its intraguild predator: distance-sensitive or habitat-mediated avoidance? Anim Behav 74:1607-1616

Stürzer SJ (1998) Habitatwahl des Habichtskauzes Strix uralensis im Nationalpark Bayerischer Wald. Orn Anz 37:193-202 (in German)

Sunde P (2011) What do we know about territorial behavior and its consequences in tawny owls? In: Zuberogoitia I, Martínez JE (eds) Ecology and conservation of European forest-dwelling raptors. Diputación Foral de Bizkaia, Bilbao, pp 253-260

Swihart RK, Gehring TM, Kolozsvary MB, Nupp TE (2003) Responses of "resistant" vertebrates to habitat loss and fragmentation: the importance of niche breadth and range boundaries. Div Distrib 9:1-18

Tannerfeldt M, Elmhagen B, Angerbjörn A (2002) Exclusion by interference competition? The relationship between red and artic foxes. Oecologia 132:213-220

Tomiałojć L, Stawarczyk T (2003) Awifauna Polski. Rozmieszczenie, liczebność i zmiany. PTTP ,pro Natura”, Wrocław (in Polish)

Tschechkin AK (1997) Comparative food niche analysis of Strix Owls in Belarus. 2nd Owl Symposium, pp 456-460

Turzański M (2009a) Sowy Strigiformes Ojcowskiego Parku Narodowego i jego otuliny. [Owls Strigiformes of the Ojców National Park and its surroundings] Parki Narodowe i Rezerwaty Przyrody 28:75-90 (in Polish with English abstract)

Turzański M (2009b) Ekologia ptaków szponiastych Falconiformes, kruka Corvus corax oraz sów Strigiformes na Wyżynie Krakowskiej w 2008 i 2009 roku. [Ecology of birds of prey Falconiformes, raven Corvus corax and owls Strigiformes in the 
Cracow Upland in 2008 and 2009]. Studia i Materiały CEPL 3:95-109 (in Polish with English abstract)

von Haartman L (1968) The evolution of resident versus migratory habit in birds: some considerations. Ornis Fenn 45:1-7

Vrezec A (2003) Breeding density and altitudinal distribution of the Ural, Tawny, and Boreal Owls in North Dinaric Alps (Central Slovenia). J Raptor Res 37:55-62

Vrezec A, Kohek K (2002) Some breeding habits of the Ural Owl Strix uralensis in Slovenia. Acrocephalus 23:179-183

Vrezec A, Tome D (2004a) Altitudinal segregation between Ural Owl Strix uralensis and Tawny Owl S. aluco: evidence for competitive exclusion in raptorial birds. Bird Study 51:264-269
Vrezec A, Tome D (2004b) Habitat selection and patterns of distribution in a hierarchic forest owl guild. Ornis Fenn 81:109-118

Vrh P, Vrezec A (2006) Interspecific territorial vocal activity of the Ural Owl (Strix uralensis) towards Tawny Owl (Strix aluco), sympatric owl competitor: a playback experiment. Razprave Razreda SAZU 47:99-105

Zuberogoitia I, Martínez JA, Zabala J, Martínez JE (2005) Interspecific aggression and nest-site competition in a European owl community. J Raptor Res 39:156-159 